\title{
Erratum to: Computer Simulation of Defects in Carbonate Fluorapatite and Hydroxyapatites
}

\author{
Elena A. Kalinichenko, Aleksandr B. Brik, Valentin V. Radchuk, \\ Olga V. Frank-Kamenetskaya and Oleksii Dubok
}

\section{Erratum to:}

O.V. Frank-Kamenetskaya et al. (eds.), BiogenicAbiogenic Interactions in Natural and Anthropogenic Systems, Lecture Notes in Earth System Sciences, DOI 10.1007/978-3-319-24987-2_35 Erratum DOI 10.1007/978-3-319-24987-2_41

The spelling of the Aleksej V. Dubok name was incorrect. The name should read as "Oleksii Dubok".

The updated original online version for this chapter can be found at DOI 10.1007/978-3-319-24987-2_35 